\title{
Perfusion and visceral organ protection in patients with thoraco-abdominal aneurysm repair - our experiences
}

\author{
P Mardešić, D Zovko, M Milković, D Antunović, ZA Korda, A Škopljanac-Mačina, I Alfirević, V Juranko \\ From 23rd World Congress of the World Society of Cardio-Thoracic Surgeons \\ Split, Croatia. 12-15 September 2013
}

\section{Background}

We report our experience with 8 patients with thoracoabdominal aneurysm repair in period of 30 months (June 2010 till December 2012), in MAGDALENA Clinic for Cardiovascular Diseases, Medical University of Osijek.

\section{Methods}

We conducted a retrospective observational analysis of our experience with different approaches and perfusion techniques in patients with thoraco-abdominal aneurysm.

- Group 1: 3 patients: aortic cross-clamp, with left heart bypass, without selective organ perfusion

- Group 2: 2 patients: aortic cross-clamp, without left heart bypass, selective organ perfusion

- Group 3: 1 patient: aortic cross-clamp, with left heart bypass, selective organ perfusion

- Group 4: 2 patients: aortic cross-clamp, without left heart bypass, without selective organ perfusion

\section{Results}

Between June 2010 and December 2012, we performed 8 patients with zero mortality and one late post-operative complication, paraplegia after 48 hours. Left heart bypass duration $57 \pm 14$ minutes, aortic cross-clamp time duration $48 \pm 13$ minutes, median ICU stay was 95 hours, average hospital stay was $12 \pm 3$ days.

\section{Conclusions}

Thoraco-abdominal aneurysm repair with appropriate choice of operative technique and possibility of using left

\footnotetext{
* Correspondence: pjero99@yahoo.com

Magdalena - Clinic for Cardiovascular Diseases, Medical University of Osijek Cardiosurgery Department, Cardiovascular Perfusion Unit, Krapinske Toplice, Croatia
}

(C) 2013 Mardešić et al; licensee BioMed Central Ltd. This is an Open Access article distributed under the terms of the Creative heart bypass and/or selective organ protection provides good results by means of no mortality and low rate of postoperative complications and morbidity.

Published: 11 September 2013

doi:10.1186/1749-8090-8-S1-O216

Cite this article as: Mardešić et al:: Perfusion and visceral organ protection in patients with thoraco-abdominal aneurysm repair - our experiences. Journal of Cardiothoracic Surgery 2013 8(Suppl 1):O216.
Submit your next manuscript to BioMed Central and take full advantage of:

- Convenient online submission

- Thorough peer review

- No space constraints or color figure charges

- Immediate publication on acceptance

- Inclusion in PubMed, CAS, Scopus and Google Scholar

- Research which is freely available for redistribution

Submit your manuscript at www.biomedcentral.com/submit
( Biomed Central 